\title{
THE ROLE OF HINDUISM AND BUDDHISM IN PROMOTING INDIANNESS OUTSIDE INDIA: SCENARIOS OF SOUTHEAST ASIA
}

Rahul Das ${ }^{* 1} \bowtie$

${ }^{* 1}$ M. Phil Research Scholar, International Relations, Jadavpur University, India

DOI: https://doi.org/10.29121/granthaalayah.v8.i5.2020.147

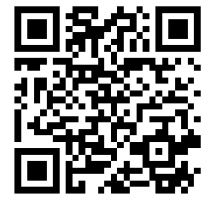

Article Type: Research Article

Article Citation: Rahul Das. (2020). THE ROLE OF HINDUISM AND BUDDHISM IN PROMOTING INDIANNESS OUTSIDE INDIA: SCENARIOS OF SOUTHEAST ASIA. International Journal of Research GRANTHAALAYAH, 8(5), 179-186. https://doi.org/10.29121/granthaa layah.v8.i5.2020.147

Received Date: 20 May 2020

Accepted Date: 31 May 2020

Keywords:

Southeast Asia

Religion

Hinduism

Indianization

Culture

Ramayana

Angkor Wat

\section{ABSTRACT}

Hinduism or Sanatana Dharma is considered to be the oldest religion in the world (Fowler 1997, p1). This religion originated in India. Similarly, India is also the birthplace of Buddhism. Apart from trade, religion was one of the means of inter-state communication and proximity in ancient times. It is through religion, ancient Indian civilization developed good relations and closeness with different parts of the world, one of which was Southeast Asia. Though Marx opined "Die Religion......ist das opium des volkes" or "religion.....is the opium of people", but the positive role of religion cannot be denied in this case. Hinduism and Buddhism were the main driving force behind the Indianization or Sanskritization of Southeast Asian States. Buddhism and Hinduism are still among the most prevalent religions in this region, despite the subsequent large-scale conversion to Christianity and Islam. The influence of Indianness is evident in all the areas of this region, including ancient architecture, sculpture, art, painting, literature, language, script, lifestyle etc. These religions have never been limited to personal sphere of inhabitants of this region but have also flourished in the political and social spheres. These religions have sometimes been instrumental in unravelling colonial chains and sometimes in nation-building efforts. At present, the Government of India is very keen on finding the roots of ancient historical ties in establishing close bilateral relations with various countries, from that point of view, this following article will be considered very relevant.

\section{INTRODUCTION}

Southeast Asia is a sub-region consisting of 11 countries. It covers an area of 4,545,792 square kilometers ${ }^{1}$. With a population of $655,298,044^{2}$, this region is one of the most populous regions in the world. Islam and Buddhism are the two most prevalent religions in Southeast Asia. Apart from them followers of Hinduism, Animism, Tai folk, Taoism, Vietnamese folk live here. 42\% of this region's inhabitants have now embraced Islam, numbering about 242

\footnotetext{
${ }^{1}$ Southeast Asia. Wikipedia. Retrieved from https://en.m.wikipedia.org/wiki/Southeast_Asia ${ }^{2}$ Ibid.
} 
million ${ }^{3}$. On the other hand, number of Buddhists in the region is about 190-205 million4. Compared to these two religions, the number of people of other religions in this region is much less.

The influence of Indianness on Southeast Asia was most noticeable from 290 BC to the 15th century ${ }^{5}$. kings of India's north eastern coastal region-maintained trade relations with southeast Asian countries such as Burma, Thailand, Indonesia and Cambodia which led to cultural, social, economic as well as religious exchanges between these two regions. Thus the 'Indianization' or 'Sanskritization' of this region took place under the direct and indirect influence of India. Kingdoms that were formed in this region under the influence of Indianization were initially Hindu and Mahayana Buddhists. Examples include Champa kingdom in Central Vietnam, Sriwijayan in Sumatra, Funan in Combodia, Khmer in Indochina, Lankasuka in Malay Peninsula, Medang, Majapahit and Singhasari Kingdoms in Java, Bali and Philippines ${ }^{6}$. Hinduism and Buddhism as one of the elements of Indian culture have significantly influenced the languages, literature, culture, calendar, traditions belief system of the civilizations that have developed in this region.

The history of mainland India's connection with Southeast Asia has been narrated in Puranas. According to Ramayana, Ramachandra sent Sugriva's vanar sena to Yawadvipa, the Island of Java, in search of Sita ${ }^{7}$. This region had a lot of contact with South India in particular. This connection was exacerbated when the Chola dynasty of India conquered Southeast Asia. The kingdom of Tarumangara or Taruma, which was established in West Java in 400 BC, was also influenced by Indianness, the Taruma kings were worshipers of Vishnu. The Kalingaa kingdom that was established in Central Java in the $6^{\text {th }}$ Century was also named after the Kalinga province of India. Today, Southeast Asia is home to large number of Indian diaspora, mostly Hindus. Apart from them, Balinese and Tenggerese minorities of this region are also Hindus. ${ }^{8}$ The Balinese are about 4.2 millions in number, or $1.7 \%$ of Indonesia's total population. The Tenggerese tribe has a population of over 1 million. A large part of the people of the Cham tribe are Hindus. They number about 4000 in Bangkok and Thailand combined. There are currently 80,400 Hindus living in Myanmar. According to the 2005 census, there are 52,631 Hindus in Thailand. Although not declared by the government, about 50,000 Hindus live in Vietnam. Hindus make up 6.3\% of Malaysia's population, numbering nearly 1.78 million. Similarly, $5.1 \%$ of Singapore's population is Hindu, numbering about 1.58 million. $1 \%$ of people in the Philippines practice Hinduism.

Therefore, it is true that the association of this region with Hinduism is very ancient. The common form of Hinduism here is basically Shaivism, i.e. their deity is Shiva. The second largest form of Hinduism here is Vaishnavism 9 . The disciples of the God Vishnu are called Vaishnavas. This region is also home to worshippers of the Brahma deity. It is said that the old name of Myanmar 'Burma' originated after the name of Brahma ${ }^{10}$. The region was later influenced by Tantra, which was associated with both Hinduism and Buddhism. The Khmer Kings were worshipers of 'Hari-Hara', an amalgamation of Vishnu and Shiva11. Statue of this deity have been found in Badami cave in North Karnataka, India, which is a clear indication of the close ties between India and Southeast Asia in ancient times ${ }^{12}$. Hari-Hara was worshipped mainly in Cambodia, one of the countries of this region. Statues of Ganesha, Skanda, Nandi (Lord Shiva's bull), Garuda (the Eagle mount of Vishnu), Lakshmi have been found in various parts of Southeast Asia. The existence of another mixed god like Hari-Hara has been found here, namely 'Ardhanarisvara', a combination of Shiva and Parvati13. Just as the Hindus consider the waters of the Ganges to be sacred, so the water of the river flowing from the Phnom Kulen hill was also considered sacred in this region,

\footnotetext{
${ }^{3}$ Islam in Southeast Asia. Wikipedia. Retrieved from https://en.m.wikipedia.org/wiki/Islam_in_Southeast_Asia

${ }^{4}$ Buddhism in Southeast Asia. Retrieved from https://en.m.wikipedia.org/wiki/Buddhism_in_Southeast_Asia

5 History of Indian Influence on Southeast Asia. Wikipedia. Retrieved from

https://en.m.wikipedia.org/wiki/History_of_Indian_influence_on_Southeast_Asia

${ }^{6}$ Hinduism in Southeast Asia. Wikipedia. Retrieved from https://en.m.wikipedia.org/wiki/Hinduism_in_Southeast_Asia

${ }^{7}$ Kapur, Kamlesh 2010: 465

${ }^{8}$ Hinduism in Southeast Asia. Wikipedia. Retrieved from https://en.m.wikipedia.org/wiki/Hinduism_in_Southeast_Asia

9 The spread of Hinduism in Southeast Asia and the Pacific. Britannica. Retrieved from

https://www.britannica.com/topic/Hinduism/The-spread-of-Hinduism-in-Southeast-Asia-and-the-Pacific

${ }^{10}$ Hinduism in Myanmar. Wikipedia. Retrieved from https://en.m.wikipedia.org/wiki/Hinduism_in_Myanmar

${ }^{11}$ Hinduism in Southeast Asia. Encyclopaedia. Retrieved from https://www.encyclopedia.com/environment/encyclopedias-

almanacs-transcripts-and-maps/hinduism-southeast-asia

12 Ibid.

13 Ibid.
}

International Journal of Research -GRANTHAALAYAH 
according to various inscription. To the Shaivites, Shiva was mainly worshipped as a Linga or Lingam, is an abstract representation of Lord Shiva. The Shaivites of this region believed that Shiva's two wives were Uma and Ganga. The significance of Shiva in this region can be understood by visiting the Prambanan Temple in Jakarta, Indonesia. Although there are temples of Vishnu and Brahma here, the main Shrine is dedicated to Shiva. The Hindu God Indra bears a resemblance to the Thagyamin deity worshipped in Myanmar. In Myanmar, Lord Shiva was known as Paramizwa and Vishnu as Withano. In this country, Thurathadi is worshipped as the Goddess of Knowledge, with whom Saraswati is found to be similar. In the same way, the resemblance of the Goddess Lakshmi to the Goddess of wealth in Thailand, Nang Kwak, is remarkable ${ }^{14}$.

Apart from religious field, the has been heavily influenced by Hinduism in terms of culture. Different elements of Hinduism by folk artist have spread in different parts of Southeast Asia from generations. And these elements have blended aptly with the core culture of this region. The Hindu epics Ramayana and Mahabharata are prevalent in almost every country in this region. In addition to the main stories of the epics, some of the scattered events and anecdotes from respective regions have been added. As the stories spread, they gradually became an integral part of the life and culture of the local people. The name of Ramayana in Malaysia is 'Hikayat Seri Rama'15, in Cambodia it is known as 'Reamker'16. The Thai version of Ramayana is called 'Ramakien'17 and Myanmar it is also known as 'Kama Zatdaw'18. In Indonesia the Ramayana, performed by movable 'Wayang' leather puppets, very popular with the masses $^{19}$.

Various Indian Hindu festivals are celebrated with great pomp in southeast Asian countries. For example, Diwali is one of the most celebrated festivals in Singapore. Another influence of Hinduism on the public life of this region is seen in the application of Sanskrit language. In ancient India, Brahmins were experts in astrology, in addition to this, they were also admired for their sharp political knowledge. The kings of Southeast Asia used to invite Indian Brahmins to appoint themselves as chief advisors. All these Brahmins appointed as advisors used Sanskrit language in royal affairs and administrative works ${ }^{20}$. They were the ones who spread Sanskrit as a written language in this region. Influenced by the Sanskrit language, the scripts of the local languages were created, resulting in a wide range of similarities between the alphabets of these languages and Sanskrit alphabet. Sanskrit is the earliest form of the written languages currently used in Laos, Myanmar, Cambodia and Thailand, various ancient scripts and documents bear witness to this. At that time Sanskrit was used in all legal documents and in other minor fields only local languages were used. Even the legal framework of these Countries was very much similar to the legal framework of India ${ }^{21}$. Even today, Sanskrit words are associated with the names of the inhabitants of this region, especially Indonesia. Sukarno, for example, is a very popular name in Indonesia. Despite Indonesia being a Muslim-majority country, the country's national symbol bears the symbol of Garuda, the eagle mount of the Hindu God Vishnu, even the national airline of that country is known as 'Garuda International'.

In the social sphere too, the influence of Hinduism in this region is immense. Manusmriti has been translated into various regional languages here, with original theme unchanged but various sub-stories attached to it ${ }^{22}$. Main theme of Manusmriti is the caste system, which was observed in Cambodia during the Khmer dynasty. Most of the people under this hierarchical system were farmers and fisherman. The Kshatriyas were elite people including kings, warriors, army Chiefs. Brahmins or Priests also existed in the system, they were highly respected in the society ${ }^{23}$. The lower classes of the society consist of various workers, potters, blacksmiths, masons, and others. Among the Brahmins and Kshatriyas, the influence of caste system was greater than that of the lower castes. But, the inferiority of women as described in the Manusmriti was not followed at all in the Southeast Asian countries. Women were

${ }^{14}$ Ibid.

${ }^{15}$ Gallop, Annabel 2014

${ }^{16} \mathrm{Ibid}$.

${ }^{17}$ Ramakien, Wikipedia. Retrieved from https://en.m.wikipedia.org/wiki/Ramakien

${ }^{18}$ Gallop, Annabel 2014

${ }^{19}$ Sengupta, Jayshree, 2017

${ }^{20}$ Hinduism in Southeast Asia. Encyclopedia. Retrieved from https://www.encyclopedia.com/environment/encyclopedias-almanacstranscripts-and-maps/hinduism-southeast-asia

${ }^{21} \mathrm{lbid}$.

${ }^{22} \mathrm{lbid}$.

${ }^{23} \mathrm{Ibid}$. 
especially powerful here. Inheritance of kingdom like in India was determined not only on the basis of paternal lineage, but also on the basis of maternal lineage. The 'Sdok Kak Thom' inscription, which is the main document of antiquity in the social and cultural spheres of Cambodia, mentions many kings who inherited their Kingdom according to their matriarchy ${ }^{24}$. In those days women held important positions, many religious and charitable projects were developed with their interest and donations. Indra-laksmi, Kambaja-raja-laksmi, Jayraja devi and other influential and powerful women of that time are known from the script. Although Manusmriti was not followed, it cannot be denied that this practice of empowering women has been adopted from Indian version of Hinduism. As women empowerment was practiced in South India, Southeast Asia is thought to have followed that tradition ${ }^{25}$.

In terms of architecture, sculpture and art forms, Hindu influence is clearly visible in this region. Hundreds of Hindu temples can be seen in almost every country of this region. The two most notable temples are the temple of lord Jonggrang, in Indonesia built in the middle of $9^{\text {th }}$ century, popularly known as Prambanan Temple and the Ankor Wat Temple, constructed in the mid $20^{\text {th }}$ century, also located in Indonesia.

The Prambanan Temple is located in Jakarta, Indonesia. It has 250 smaller temples in the complex, the highest being the Shiva temple which is 47 meters high. There are also temples of Vishnu and Ganesha. A princess, lord Jonggrang has her own temple, who is sometimes identified with Durga in that region. The story of Ramayana is engraved on the temples in the form of paintings ${ }^{26}$.

like Prambanan, Hindu architectural style has been followed in Ankor Wat. Remarkably, it is the largest Hindu temple in the world. King Suryavarman II built this temple and dedicated it to Vishnu. Needless to say, the main deity worshipped in the temple is Vishnu ${ }^{27}$. Apart from Ramayana, Mahabharata, Bhagavata Purana, Harivamsa Purana also engraved in the form of mythological paintings on this temple.

The Murugan Temple in Batu cave is Malaysia is one of the most iconic Hindu architectural monuments, with a 42.7-metre-high statue of the God Murugan ${ }^{28}$. Just as Diwali in the worship of Kali, Navaratri in the worship of Durga are celebrated with razzle-dazzle, so the Murugan festival or 'Thaipusum' is celebrated with equal grandeur in this temple. The Besakih Temple or 'Temple of Mother' in the Indonesia is the most important, the largest and holiest temple of the Hindu religion in Bali ${ }^{29}$. Its height is nearly 1000 meters, the whole temple complex consists of 23 small temples. Also, worth mentioning the 'Nat Hlaing Kyaung' temple of Vishnu in Myanmar, which was established in the $11^{\text {th }}$ century ${ }^{30}$. Aside from temples, the walls of various government and private buildings in this region are engraved with images of Hindu mythological characters of Ramayana, Mahabharata as well as Nagas and Garudas of Puranas. These indicate southeast Asia's long-standing relationship with Hinduism.

The popularity of Hinduism has been declining since the $13^{\text {th }}$ century. On the other hand, the popularity of Buddhism was gradually increasing. In the beginning there was no significant difference between these two religions, Buddhism was practiced in Hindu places of worship. Successively, the extent of Buddhism became apparent over time. From $11^{\text {th }}$ to $13^{\text {th }}$ centuries, the golden age of Buddhism continued to this region. Later, the lion's share of this religion converted to Islam. Currently, there are a large number of Buddhists in this region, second only to Muslims in terms of numbers, but the number of Hindus has decreased a lot than before.

There are currently about 190-205 million Buddhists in Southeast Asia, making it the second largest religion in this region after Islam. 35\%-38\% of Buddhists worldwide have settled in this region. Thailand has the largest Buddhist population. 95\% of the country's population is Buddhist, numbering 63.75 million. The number of Buddhist living in Myanmar is 48 million, which is $89 \%$ of the total population of the of this country. Buddhists make up half of Vietnam's total population, numbering 44 million. 95\% of Cambodia, or about 14 million citizens, are Buddhist. $20 \%$ of Muslim-majority Malaysian are Buddhists. The 5 million people in communist Laos are Buddhist, accounting for about $70 \%$ of the country's population. Although Indonesia is an Islamic state, Buddhists make-up approximately $2 \%$ of the country's population, numbering 4.75 million. Nearly 65000 or $13 \%$ of Brunei's citizens are Buddhists.

\author{
24 Ibid. \\ 25 Ibid. \\ 26 Ibid. \\ 27 Ibid. \\ 28 Ibid. \\ ${ }^{29}$ Besakih Temple. Wikipedia. Retrieved from https://en.m.wikipedia.org/wiki/Besakih_Temple \\ ${ }^{30}$ Nathlaung Kyaung Temple. Retrieved from https://en.m.wikipedia.org/wiki/Nathlaung_Kyaung_Temple
}


About 2 million Buddhists live in Singapore which is 33\% of their total population. 1\% of people in the Philippines practice Buddhism ${ }^{31}$.

Different types of Buddhism are observed in different regions. Inscriptions from the southern part of southeast Asia were written in Pali, indicate that this region was largely devoted to Theravada Buddhism. The inscriptions from the north, on the other hand, were written in Sanskrit. The inhabitants of this part believe in Mahayana Buddhism ${ }^{32}$. Tantrism was influential among the believers in the Mahayana Buddhism of Southeast Asia. Theravada Buddhism first spread from India to Sri Lanka, then to Cambodia, Laos and the southern part of Myanmar. On the other hand, Mahayana Buddhism spread from India and China to Southeast Asia in the 1st and 2nd centuries. Mahayana Buddhism expanded by sea and became very popular in Vietnam under Chinese influence. Just as Theravada Buddhism originated from South India, North India is the birthplace of Mahayana Buddhism. In 250 BC, the Indian empire of Mourya Dynasty, Ashoka sent Buddhist monks to Myanmar or former Burma to propagate Theravada Buddhism. The Mon kings of Burma welcomed them and many people in their Kingdom voluntarily converted to Buddhism. Thus, began the journey of Theravada Buddhism in this region. The Ceylonese monks later maintained this trend. In the $3^{\text {rd }}$ Century BC, there was disagreement amount Ceylonese monks about the differences in practices between some councils of Bhikkhu monks and Vajjian monks. Since then, these two branches of Buddhism have become quite separate ${ }^{33}$.

Three different regions of Southeast Asia have been influenced differently by Buddhism. The three regions are Malaysia and Indonesia, Myanmar and Mekong Delta and Vietnam, respectively ${ }^{34}$. It is believed that King Ashoka sent two of his envoys, Sona and Uttara, to the Malaysian peninsula or any part of Indonesia to propagate Buddhism, known as the 'Land of Gold' or 'Suvarnabhumi'. Before the $5^{\text {th }}$ century BC, the Indian monk Gunavarmana successfully preached Buddhism in this region. In the $7^{\text {th }}$ century, the Srivijaya kings played a pivotal role in the spread of Buddhism. The Shailendra kings patronized and propagated Mahayana and Tantric Buddhism from $7^{\text {th }}$ to $9^{\text {th }}$ century35. The Myanmar-Mekong delta is the second part of this region where Buddhism flourished. The local Mons and Burmese, however, claims that this is the real Suvarnabhumi, where Ashoka sent his envoys to preach Buddhism. Conservative Hinayana Buddhism was first practiced in this region, but later in the $12^{\text {th }}$ and $13^{\text {th }}$ centuries, under the patronage of King Jayvarman VII, Mahayana and Vajrayana Buddhism were introduced. The Theravada reforms that began in Sri Lanka after the $11^{\text {th }}$ century gradually overwhelmed this region, which remained intact in the $20^{\text {th }}$ century also. In the $1^{\text {st }}$ millennium CE, Buddhism reached Vietnam by sea trade from China. At that time, Vietnam was under Chinese rule. However, Mahayana and Hinayana Buddhism spread to the two Indian-influenced States of Champa and Funan in Vietnam. But Buddhism was not propagated in these areas in any organized way. Buddhism was propagated in Vietnam on a long-term and organized basis through Zen and Pure Land tradition, which came from China ${ }^{36}$. Gradually Tantrism, Daoism and Confucianism entered Vietnam. When Communist regime began in Vietnam, many Buddhist monks turned to self-immolation in protest during the reign of Ngo Dinh Diem. During this time, obstacles were created for Buddhism, but Buddhism remained in its glory.

A review of the history of southeast Asia reveals that the monarchy has been in place for a long time, with Buddhism playing a major role. Because Buddhism explains a cosmology where 'Chakkavattin' or the king is the Central figure in society and the whole community depends on him ${ }^{37}$. Buddhism promotes the existence of kings and provides spiritual explanations. Such images have been found in texts such as 'Agganna Suttanta' and 'Digha Nikya'. These texts further state that the king is the protector of all because he ruled The Kingdom following the 'Dhamma', so the king mast be a 'Khattiya', or lord of the fields. If the king's authority is maintained uninterruptedly, peace will prevail in the kingdom, in which case the Buddhist monks will be able to survive, and the 'Nibbaba' or Nirvana will be achieved through austerities ${ }^{38}$.

\footnotetext{
${ }^{31}$ Buddhism in Southeast Asia. Retrieved from https://en.m.wikipedia.org/wiki/Buddhism_in_Southeast_Asia

32 Ibid.

33 Ibid.

${ }^{34}$ Buddhism: Southeast Asia. Britannica. Retrieved from https://www.britannica.com/topic/Buddhism/Southeast-Asia

35 Ibid.

36 Ibid.

${ }^{37}$ Buddhism: Buddhism in Southeast Asia. Encyclopedia. Retrieved from

https://www.encyclopedia.com/environment/encyclopedias-almanacs-transcripts-and-maps/buddhism-buddhismsoutheast-asia

38 Ibid.
} 
The history of these cordial relationship between the king and the Buddhist monks is evident from the construction of various Chaityas, Viharas and Stupas in this region, which were formed by the grace of the king. These are found in large numbers in ancient cities like Borobudur, Ankor and Bagan (Pagan) ${ }^{39}$. During the reign of the Shailendra kings in the $9^{\text {th }}$ Century, the stupa of Borobudur was built in the present city of Jakarta, which is one of the oldest examples of Buddhist architecture. The Mahayana influence of this period is known through the depiction of stories like 'Lalitovistara', 'Divyavandana', 'Jatakamala' etc. in this architecture. There are 72 perforated, hollow stupas on three huge circular scaffoldings in which Buddha statues are curved. This relationship between king and Buddhism is more evident in the architecture of Ankor, Cambodia, especially through the presentation of Devaraja (God King) concept. It was built by Khmer King Jayavarman II. At that time Shaivism was the State religion, that is why Linga was made here. The concept of Devaraja took Buddhist form during the reign of king Suryavarman I. This idea came to fruition during the reign of King Jayavarman VII, who built the famous Bayon Temple, one of the finest examples of Buddhist architecture. Thus, the idea of Devaraja practically culminated in the idea of Buddha Raja. There are about 4000 Buddhist stupas in the Bagan region, which are outstanding examples of Buddhist architecture. Among the few impeccable architectures built under the influence of Mahayana Buddhism is the Sulamani Temple built by King Narapatisithu ${ }^{40}$, the Gawadapalin Temple constructed by King Sithu I and King Htilominlo ${ }^{41}$, Anand Temple built by King Kyanzitthu ${ }^{42}$ and many more.

In modern Times, Buddhism continued to face a variety of problems in southeast Asia. These problems were exacerbated after the colonial powers entered the region. This region was mainly colonized by Britain and France. Since 1830, Christian missionaries from Europe have been arriving and preaching Christianity. Western modernity posed a challenge to Conservative Buddhist culture. Under the influence of modernity, a number of reforms programmes were adopted in Buddhism as well ${ }^{43}$.

Buddhism has played a significant role in overthrowing colonial rule in countries like Thailand, Myanmar, Cambodia, Laos, at the same time it has played an instrumental role in the development of nationalism as well. The contribution of Buddhism in conducting the freedom movement of this region in various ways is huge. Myanmar's Young Men's Association or YMBA played a direct political role in countering colonial powers. Take, for example, the 'No Footwear Controversy' of 1918, where this association forced Europeans to enter Buddhist Shrines and Pagodas without wearing shoes, which was previously denied by European colonial masters. There was a monk named you U Ottoma who was imprisoned for calling for a boycott of a government-funded election. A monk named U Wisara, who sacrificed his life in prison by fasting for the freedom movement. Apart from playing an important role in independence movement, the role of Buddhism in nation building process is also memorable. When $U$ Nu became the Prime Minister of Burma in 1948, he placed Buddhism at the center of all political activities. He developed Buddhist socialism by abandoning Marxism prevalent in that region at that time. Similarly, in 1960 Buddhist monks in Vietnam hastened the fall of Diem government. Later under the leadership of Tai Quang and Thich Thien Minh, the 'United Buddhist Association' began to play a significant role in the Vietnamese State affairs. In Cambodia King Sihanouk followed Buddhist socialism in his political activities. In Thailand, Vijruvadh called for nation building following Buddhism and introduced Buddhist-centered education system ${ }^{44}$.

This means that Buddhism in this region was not only limited to the personal affairs of the people as a domestic religion. Historically, this religion has greatly influenced the lives of the people of Southeast Asia extending from social sphere to the political sphere.

The history of Hinduism and Buddhism is very ancient, and it no exaggeration to call Hinduism the oldest religion in the world. India is generally considered to be the source of these religions. Before the advent of Christianity and Islam, the two most prevalent religions in the world, Indian civilization influenced various civilizations in different parts of the world by its own religions. It is mainly through Indian religion that Indian culture, languages, foods, customs and lifestyles gradually penetrated into various civilizations of the world and

\footnotetext{
39 Ibid.

40 Sulamani Temple. Wikipedia. Retrieved from https://en.m.wikipedia.org/wiki/Sulamani_Temple

${ }^{41}$ Gawdawpalin Temple. Wikipedia. Retrieved from https://en.m.wikipedia.org/wiki/Gawdawpalin_Temple

${ }^{42}$ Anand Temple. Wikipedia. Retrieved from https://en.m.wikipedia.org/wiki/Ananda_Temple

43 Buddhism: Buddhism in Southeast Asia. Encyclopedia. Retrieved from

https://www.encyclopedia.com/environment/encyclopedias-almanacs-transcripts-and-maps/buddhism-buddhismsoutheast-asia

44 Ibid.
}

International Journal of Research -GRANTHAALAYAH 
became integrated with them. This is how Indianization or Sanskritization took place. Southeast Asia is one of the most influenced parts of world by India. Although India does not share borders directly with any of the Southeast Asian States except Myanmar, the influence that India has had on these countries through religions remains intact for thousands of years.

\section{SOURCES OF FUNDING}

None.

\section{CONFLICT OF INTEREST}

None.

\section{ACKNOWLEDGMENT}

None.

\section{REFERENCES}

[1] Dumarcy, Jacques. 1986. The Temples of Java. Translated by Michael Smithies. Singapore.

[2] Hinduism In Southeast Asia. 2020. Encyclopedia. Retrieved from https://www.encyclopedia.com/environment/encyclopedias-almanacs-transcripts-and-maps/buddhismbuddhism-southeast-asia

[3] Hinduism is Southeast Asia. Wikipedia. $\quad$ Retrieved from https://en.m.wikipedia.org/wiki/Hinduism_in_Southeast_Asia

[4] History of Indian influence on Southeast Asia. Wikipedia. Retrieved from https://en.m.wikipedia.org/wiki/History_of_Indian_influence_on_Southeast_Asia

[5] Brennan, Elliot. 2014. Religions in Southeast Asia: Diversity and the threats of extremes, The Interpreter. Retrieved from https://www.lowyinstitute.org/the-interpreter/religion-southeast-asia-diversity-andthreat-extremes

[6] Hindu Influence and Southeast Asia. 2011. Asia Sentinel. Retrieved from https://www.asiasentinel.com/p/hindu-influence-and-southeast-asia

[7] The spread of Hinduism in Southeast Asia and the Pacific. Britannica. Retrieved from https://www.britannica.com/topic/Hinduism/The-spread-of-Hinduism-in-Southeast-Asia-and-the-Pacific

[8] Murphy. Anne. The Religions of South Asia. Center for Global Education. Retrieved from https://asiasociety.org/education/religions-south-asia

[9] Pillalamarri, Akhilesh. 2018. How India Influenced Southeast Asian Civilization. The Diplomat. Retrieved from https://thediplomat.com/2018/10/how-india-influenced-southeast-asian-civilization/

[10] Sengupta. Jayshree. 2017. India's cultural and civilizational influence on Southeast Asia. ORF. Retrieved from https://www.google.com/amp/s/www.orfonline.org/expert-speak/indias-cultural-and-civilizationalinfluence-on-southeast-asia/

[11] Buddhism in Southeast Asia. Wikipedia. $\quad$ Retrieved from https://en.m.wikipedia.org/wiki/Buddhism_in_Southeast_Asia

[12] Tai Thu, Nguyen. 2008. The History of Buddhism in Vietnam. Washington DC: The Council for Research in Values and Philosophy.

[13] Lester, Robert C. 1973. Theravada Buddhism in Southeast Asia. United States: Ann Arbor Paperbacks.

[14] Inspiring Heritage of Indonesia. TWC. Retrieved from http://borobudurpark.com/en/home-2/

[15] Marado, John. 1976. Buddhism in the Modern World. New York: Macmillan

[16] Buddhism in Southeast Asia. The Buddhist World. Retrieved from http://www.buddhanet.net/elearning/buddhistworld/southeast.htm 
The Role of Hinduism and Buddhism in Promoting Indianness Outside India: Scenarios of Southeast Asia

[17] Berzin, Alexander. Spread of Buddhism in Asia. Study Buddhism. Retrieved from https://studybuddhism.com/en/tibetan-buddhism/about-buddhism/the-world-of-buddhism/spread-ofbuddhism-in-asia

[18] Buddhism: Buddhism in Southeast Asia. 2020. Encyclopedia. Retrieved from https://www.encyclopedia.com/environment/encyclopedias-almanacs-transcripts-and-maps/buddhismbuddhism-southeast-asia

[19] Southeast Asia. Britannica.

Retrieved from https://www.britannica.com/topic/Buddhism/Southeast-Asia 